Demitri A. Cozanitis MBснв MD DTM\&H, Olli Erkola MD, Ulla-Maija Klemola MD PH D, Virve Mäkelä MD

\title{
Precurarisation in infants and children less than three years of age
}

Sixty patients less than three years of age about to undergo adenoidectomy or endoscopy were divided into three groups of 20 each according to age (0-11 months, 12-23 months, 24-35 months). Before the induction of anaesthesia with thiopentone, either tubocurarine $0.05 \mathrm{mg} \cdot \mathrm{kg}^{-1}$ or normal saline was given at random in a double-blind fashion. Three minutes later, the children received succinylcholine 1.5 or $1.0 \mathrm{mg} \cdot \mathrm{kg}^{-1}$, respec. tively. Muscle movements were graded according ta a four-point scale. Blood was sampled for creatine kinase (CK) activiry before anaesthesia and on the following morning. When all age groups were combined, there was a significant reduction of muscle movements in patients who had received tubocurarine pretreat. ment. Serum $C K$ activity rose significantly when saline pretreat ment was used in children over the age of one year bu not in the infants, despite the presence of muscle movements following succinylcholine administration.

The response of muscle to an intravenous injection of succinylcholine is an evanescent stimulation of some muscle fibres. Generally, this muscle activity, which is referred to as fasciculation, begins with the muscles of the eyelids and spreads quickly over the face and neck to the trunk. Finally, gross movements of one or more of the limbs may take place before flaccid paralysis and blockade of myoneural conduction occurs.

Mayrhofer showed that if a dose of $0.05 \mathrm{mg} \cdot \mathrm{kg}^{-1}$ of tubocurarine is administered before succinylcholine, the fasciculations are controlled. Tanmisto and Airaksinen ${ }^{2}$

\section{Key words}

ANAESTHESIA: paediatric; NEUROMUSCUI,AR RELAXANTS: succinylcholine; ENZYMES: creatine kinase.

From the Otolaryngological Hospital and the Children's Hospital of Helsinki University Central Hospital, Helsinki, Finland.

Address correspondence to: Dr, D. A. Cozanitis, Department of Anaesthesia, Helsinki University Central Hospital, SF-00290 Helsinki 29, Finland. reported that the fasciculations provoked by the depolarising relaxant produced an elevation of serum creatine kinase (CK) activity. Miller ${ }^{3}$ noted that if tubocurarine is given before succinylcholine, the elevation of $\mathrm{CK}$ is reduced or eliminated.

All the above reports pertain to individuals over the age of three years. In younger patients, fasciculations are not normally seen following intravenously administered succinylcholine. Instead, only gross movements of the limbs are usually secn. Salem et al. ${ }^{4}$ described fasciculations from succinylcholine $1.1 \mathrm{mg} \cdot \mathrm{kg}^{-1}$ as being absent or minimal in infants who had been premedicated with hyoscine and in children up to three years of age who had received hyoscine and morphine before anaesthesia was induced with either thiopentone or halothane

The effect of a small dose of tubocurarine before succinylcholine in children less than three years of age has not been examined and neither therefore in this context have the levels of scrum CK. We decided to examine the effect of "precurarisation" on succinylcholine-induced muscle movements and its effect, if any, on levels of serum $\mathrm{CK}$ in patients aged less than three years.

\section{Methods}

Sixty caucasian infants and children (ASA physical status 1) scheduled to undergo adenoidectomy or endoscopy were studied. The protocol had been approved by the ethics committees of both the Children's Hospital and the Otolaryngological Hospital. The parients had not been receiving any drug therapy and had not had an intramuscular injection for at least one month before the anaesthetic. They were divided into three groups of twenty each according to their ages: (1) 0-11 months, (2) 12-23 months and (3) 24-35 months. In the morning, oral premedication given about 60 minutes before the start of anaesthesia consisted of Triclos Liquid (sodium salt of trichloroethyl phosphate, Merrell Dow) $0.7 \mathrm{ml} \cdot \mathrm{kg}^{-1}$ and atropine $0.03 \mathrm{mg} \cdot \mathrm{kg}^{-1}$ given together in $7 \mathrm{ml}$ of fruit juice.

In the operating theatre, ECG electrodes were applied and a sphygmomanometer was used for blood pressure measurement. A peripheral vein was then cannulated and 
TABLE I Demographic and CK data

\begin{tabular}{|c|c|c|c|c|c|c|}
\hline Treatment & $\begin{array}{l}\text { Age group } \\
\text { (months) }\end{array}$ & $\begin{array}{l}\text { Sex } \\
M / F\end{array}$ & $\begin{array}{l}\text { Age } \\
\text { mean } \pm S D \\
(\text { mon(hs) }\end{array}$ & $\begin{array}{l}\text { Weight } \\
\text { mean } \pm S D \\
(\mathrm{~kg})\end{array}$ & $\begin{array}{l}\text { CK, } \\
\text { median } \\
\text { (range) } \\
\left(W U \cdot L^{-1}\right)\end{array}$ & $\begin{array}{l}\mathrm{CK}_{2} \\
\text { median } \\
\text { (range) } \\
\left(\mathrm{JU} \cdot \mathrm{L}^{-1}\right)\end{array}$ \\
\hline \multirow[t]{3}{*}{ Tubocurarine } & $0-11$ & $6 / 4$ & $9.1 \pm 1.59$ & $8.5 \pm 1.43$ & $\begin{array}{l}119 \\
(72-429)\end{array}$ & $\begin{array}{l}110 \\
(48-806)\end{array}$ \\
\hline & $12-23$ & $8 / 2$ & $19.5 \pm 2.99$ & $12.9 \pm 2.02$ & $\begin{array}{l}95 \\
(52-186)\end{array}$ & $\begin{array}{l}86 \\
(63-136)\end{array}$ \\
\hline & $24-35$ & $5 / 5$ & $27.7 \pm 3.23$ & $13.5 \pm 1.51$ & $\begin{array}{l}88 \\
(54-176)\end{array}$ & $\begin{array}{l}81 \\
(48-163)\end{array}$ \\
\hline \multirow[t]{3}{*}{ Saline } & $0-11$ & $9 / 1$ & $8.3 \pm 1.23$ & $8.8=1.23$ & $\begin{array}{l}198 \\
(55-684)\end{array}$ & $\begin{array}{l}211 \\
(49-472)\end{array}$ \\
\hline & $12-23$ & $8 / 2$ & $18.1 \pm 3.57$ & $11.4 \pm 1.58$ & $\begin{array}{l}132 \\
(71-426)\end{array}$ & $\begin{array}{l}273^{*} \\
(105-4405)\end{array}$ \\
\hline & $24-35$ & $4 / 6$ & $28.4 \pm 3.27$ & $13.2 \pm 1.32$ & $\begin{array}{c}99 \\
(42-147)\end{array}$ & $\begin{array}{l}121 \dagger \\
(63-592)\end{array}$ \\
\hline
\end{tabular}

$* p<0.05$.

tp $<0.01$

$2 \mathrm{~m}$ ? blood was withdrawn for total serum creatine kinase (CK) activity, measured within four hours according to the Recommendation of the Scandinavian Committee on Enzymes. ${ }^{5}$ The normal upper limits (95th percentile) in the laboratory are: $170 \mathrm{I}$.U. $\cdot \mathrm{L}^{-1}$ for infant (<one year of age) boys and girls and respectively, 109 and $100 \mathrm{I} . \mathrm{U} . \mathrm{L}^{-1}$ for boys and girls from one to four years of age. Within each age group, in random order and in a double-blind fashion, half of the patients were given tubocurarine (Tubarine, Wellcome) $0.05 \mathrm{mg}^{\prime} \mathrm{kg}^{-1}$ IV. This tubocurarine preparation is free of pain on injection. ${ }^{6}$ The remaining children received an equal volume of normal saline solution. At $0 \mathrm{~min}$, either tubocurarine or saline was given. Thiopentone $5 \mathrm{mg} \mathrm{kg}^{-1}$ IV was injected and when the loss of the eyelash reflex occurred, the patient was ventilated with 100 per cent oxygen through a modified Jackson-Rees circuit. At $3 \mathrm{~min}$ (the optimal time interval for precurarisation $)^{7}$ and without the anaesthetist knowing which dose was being used, succinylcholine 1.5 or $1.0 \mathrm{mg} \cdot \mathrm{kg}^{-1}$ was given, depending on whether tubocurarine or saline, respectively, had been earlier administered. All drugs were given into the intravenous cannula and immediately flushed with saline.

Muscle movements were graded by the "blinded" anaesthetist as follows: $0=$ absent, $1=$ some movement but without limb flexion, $2=$ movement accompanied with flexion of either upper or lower limb(s), $3=$ exaggerated limb flexion. The trachea was intubated and the patient was ventilated with halothane $1-2$ per cent in a mixture of nitrous oxide and oxygen (2:1). A slow drip of glucose five per cent was started and the planned operative procedure was carried out. Postoperative analgesia was provided in the Recovery Room with ejther IV meperidine or with a paracetamol suppository, the latter being used exclusively later on the ward. On the following morning (21 to 24 hours later) a second blood sample was taken for total creatine kinase determination $\left(\mathrm{CK}_{2}\right)$.

Statistical analysis of the non-parametric data was with Fisher's exact probability test, the chi-square test, and Wilcoxon signed-ranks test. A one-way analysis of variance was used for parametric data. The level of statistical significance was taken at $p<0.05$.

\section{Results}

Demographic and CK data of the patients studied are given in Table I. Regarding sex, age, and weight, there were no significant differences between the groups.

Statistically, because of the small number of patients in the age groups, a dichotomous classification was used $a$ priori indicating the treatment for the muscle responses as being "effective" if graded 0 or 1 and "ineffective" when graded 2 or 3 . Table II suggests that tubocurarine provided more effective treatment than did saline, although the differences did not reach statistical significance. When, however, the three age groups were combined, a significant difference in favour of the tubocurarine treatment was found.

Mean CK activity immediately before the start of anaesthesia $\left(\mathrm{CK}_{1}\right)$ was, in the case of males, $160 \mathrm{I} . \mathrm{U} \cdot \mathrm{L}^{-1}$ and in females, $112 \mathrm{I} \cdot \mathrm{U} \cdot \mathrm{L}^{-1}, \mathrm{p}=0.10$. Due to the skewed distribution of the enzyme values, particularly for the second sample $\left(\mathrm{CK}_{2}\right)$ (Table II) the medians rather than the means were employed in the analysis of the data. When the levels of the $\mathrm{CK}_{1}$ and $\mathrm{CK}_{2}$ samples were compared, there was no significant difference for any of the age groups which had reccived tubocurarine. When 
TABLE II The effect of tubocurarine or saline before succinylcholine on muscle movements in the three age groups and all age groups combined.

\begin{tabular}{lllll}
\hline & \multicolumn{3}{c}{ Grading } \\
\cline { 3 - 4 } Age group & & Oor 1 & 2 or 3 & \\
[monihs) & Trememens & $n$ & $n$ & $p=$ \\
\hline $0-11$ & Tubocurarinc & 9 & 1 & \\
& Saline & 4 & 6 & 0.057 \\
$2-23$ & Tubocurarine & 5 & 5 & \\
$24-35$ & Saline & 1 & 9 & 0.14 \\
& Tubocurarine & 6 & 4 & \\
Combined & Saline & 1 & 9 & 0.057 \\
& Tubocurarine & 20 & 10 & \\
& Saline & 6 & 24 & 0.007 \\
\hline
\end{tabular}

saline had been given, the 12-23-month-old group and the 24-35-month-old group, but not the infants, had significant changes in their median CK values (Table I)

\section{Discussion}

This study demonstrates that the gross muscle movements which follow the intravenous injection of succinylcholine in children aged less than three years can be controlled by the prior administration of tubocararine. In children over one year of age, the muscle movements were accompanied by a rise in serum CK activity, indicating some change in the skeletal muscle biochemistry. This increase in the enzyme activity was inhibited by the pretreatment with tubocurarine. The infants in the study, however, behaved differently. Regardless of whether or not pretreatment with tubocurarine was used, serum $\mathrm{CK}$ activity temained unchanged in both groups even when muscle movements had been clearly evident in those patients who had received saline pretreatment. It is likely that in infants a degree of immaturity of neuromuscular transmission exists. In any case, it should be borne in mind that the study population was reasonably small and therefore for example, the lack of statistical significance of muscle movements in the infant and 24-35-month-age groups (Table II) may be attributed to small numbers.

Why gross muscle movements rather than fasciculations are manifested in infants and children less than three years of age is unknown. Cook and Fischer ${ }^{8}$ believe that it is related to the dilution of succinylcholine in a large extracellular fluid volume before it is distributed to a relatively small muscle mass. Mastaglia* (personal communication) suggests the relative immaturity of the neuromuscular junction to be a factor of relevance. If

*Dr. F. L. Mastaglia, The University of Western Australia, School of Medicine, October, 1982. excitation occurs simultaneously at the majority of end plates of a particular muscle, then one could envisage that grosser movements, such as flexion or extension of limbs could be produced rather than fasciculations, which represent fractional activation of muscle.

Race, sex, age, seasonal influence, diumal variation, physical activity, intramuscular injections and genetic factors may account for the wide variation of CK activity within individuals. The level of this enzyme is elevated in certain conditions, such as Duchenne muscular dystrophy, as it is in acute states such as myocardial infarction, burns and trauma, including surgery involving skeletal muscle. ${ }^{9-11}$ In the present study, the mean CK activity was higher in boys than girls but this difference did not reach statistical significance. This is in accordance with some reports ${ }^{12,13}$ although other authors observed that CK activity in boys was significantly higher than in girls. ${ }^{9.11}$ In agreement with the finding of Lane and Roses ${ }^{14}$ regarding age, the infants in the present study had higher CK levels than the children in the two older age groups, before anaesthesia.

While this study was underway, Plotz ${ }^{15}$ reported that the maximum serum $C K$ concentration occurs at about six hours after the injection of succinylcholine. Thus, in the present study where sampling was carried out 21 to 24 hours after succinylcholine administration the CK values might have been found to be more elevated, had the blood been taken earlier.

In conclusion, children between the ages of one and three years were shown to be as prone to succinylcholineinduced elevations in senum CK levels as older patients. Prior treatment with tubocurarine was effective in curtailing this incnease.

\section{Acknowledgement}

We thank most sincerely J. Desmond Merrett, $\mathrm{PhD}$, of the Department of Medical Computing and Statistics, The Queen's University of Belfast, Belfast, Northem Ireland, for kindly carrying out the analyses of the data.

\section{References}

1 Mayrhofer $O$. Die Wirksarakeit von d-Tubocurarin zur Verhutung der Muskelschmerzen nach Succinylcholin. Anaesthesist 1959; 8: 313-5.

2 Tammisto $T$, Airaksinen $M$. Increase in creatine kinasc activity in serum as sign of muscular injury caused by intermittently administered suxamethonium during halothane anaesthesia. Br J Anaesth 1966; 38: 510-5.

3 Miller RD. Advantages of giving d-lubocurarine before succinylcholine. Anesthesiology 1972; 37: 568-9.

4 Salem MR, Wong AY, Lin $Y H$. The effect of suxamethonium on the intragastric pressure in infants and children. Br J Anaesth 1972; 44: 166-9. 
5 Commiltee. The committee in enzymes of the Scandivanian Society for Clinical Chemistry and Clinical Physiology: rccommended method for the determination of creatine kinase in blood. Seand I Clin Lab Invest 1976: 36: $711-23$.

6 Cozanitis DA. Effects of nondepolarizing nequromuscular b]ocking agents on erythrocytes in vitro. Am J Hosp Pharm 1984; 41: 643-4.

7 Takki $S$, Kauste A, Kjellberg $M$. Prevention of suxamethonium-induced fasciculations by prior dose of d-tubocurarine. Acta Anaesthesiol Scand 1972; 16: 230-4.

8 Cook DR, Fischer CG. Characteristics of succinylchuline neuromuscular blockade in neonates. Anesth Analg 1978; 57: 63-6.

9 Melizer $H Y$. Factors affecting serum creatine phosphokinase levels in the general population: the role of race, activity and age. Clin Chim Acta 1971; 33: 165-72.

10 Melizer HY, Dorus E. Grunhaus L, Davis JM, Belmaker $\boldsymbol{R}$. Genetic control of human plasma creatine phosphokinase activity. Clin Genet 1978; 13: 321-6.

11 Passos MR, Gonzalez CH, Zatz M. Creatine-kinase and pyruvate-kinase activities in normal children: implications in Duchenne muscular dystrophy carrier detection. Am J Med Genet 1985; 22: 255-62.

12 Zatz $M$, Shapiro LJ, Campion DS, Oda E, Kaback MM. Serum pyruvate-kinase ( $\mathrm{PK}$ ) and creatine-phosphokinase (CPK) in progresșive muscular dystrophies, ] Nęurol Sci 1978; 36: 349-62.

13 Percy ME, Chang LS, Murphy EG, Oss I, VerellenDumoulin C. Thompson MW. Serum creatine kinase and pyruvate kinase in Duchenne muscular dystrophy carier detection. Muscle Nerve 1979; 2: 329-39.

14 Lane RJM, Roses $A D$. Variation of scrum creatine kinase levels with age in normal females: implications for genetic counselling in Duchenne muscular dystrophy, Clin Chim Acta 1981; 13: 75-86.

15 Plätz J. Doctoral thesis: Klinische Untersuchungen zur Reaktion der Skeletmuskulatur auf Succinylcholin und Halothan bei Kindern (Effekte von Diallynortoxiferin, Dant:olene und self-taming). Julius-Maximulians-Universität, Wurzburg, 1982.

\section{Résumé}

Soixante patients tous âgés de moins de trois ans et devant subir une adénoidectomie ou une enduscopie, ont été divisés selon l'âge en trois groupes de 20. Avam l'induction de l'anesthésie avec thiopentone, soit de ia DTC $0.05 \mathrm{mg} \cdot \mathrm{kg}^{-i}$ ou du salin physiologique a été administré au hasard er à double insu, Trois minutes plus tard les enfants ont reçu respectivement de la succinylcholine 1.5 ou $1.0 \mathrm{mg} \cdot \mathrm{kg}^{-1}$. Les mowements musculaires ont été gradés d' aprèr une échelle à quatre points. Du sang a été retiré pour l'activité de la créatinine kinase (CK) avant l'anesthésie et le lendemain matin. Quand tous les groupes ont été combinés on a noté une diminution significative des mouvements musculaires avec le pré-traitement d la DTC. L'activité sérique de la $\mathrm{CK}$ s'éleva significativement guand le pré-traitement au salin physiologique était wilisé pour tes enfants dont l' âge est supérieur à un an el nan chez ceux âgés de moins d' un an malgré les fasciculations musculaires. 